\title{
MENGUNGKAP ANALISIS DAN EVALUASI KEBIJAKAN TENTANG PENDIDIKAN AGAMA DAN KEAGAMAAN DI INDONESIA
}

\author{
Benny Prasetiya \\ Prodi PAI STAI Muhammadiyah Probolinggo \\ Email:prasetiyabenny@gmail.com
}

\begin{abstract}
The implementation of PP No. $55 / 2007$ is part of government intervention in religious and religious education. Every policy stipulated in its implementation certainly raises constructive criticism. Criticism that arises starts from the aspects of laws and regulations, the implementation process and the impact of a policy in the set of approaches used in this research policy research that focuses on researching policy formulation. The content analysis technique in this research is to compare the contents/formulation of PP RI No. 55 of 2007 concerning Islamic religious education with public policy theory. The researcher selects the data source that has relevance to this policy study and concludes the data for conclusions. The results of the research found were the formulation of PP RI No. 55 of 2007 related to public policy objectives that are regulative, deregulation, dynamic or stabilizing. Regulatory aspects provide restrictions and regulate the implementation of Islamic religious education. The deregulation aspect has the purpose of liberating in terms of providing education. The aspects of dynamism as the driving force for national education goals. The purpose of stabilization is intended to make adjustments to the rules so that Islamic educational institutions follow the National Education Standards.
\end{abstract}

Keywords: PP RI No. 55 of 2007; policy; Religious Education; Religion.

Abstrak: Implementasi PP No 55 Tahun 2007 bagian dari intervensi pemerintah terhadap dalam pendidikan agama dan keagamaan. Setiap kebijakan yang ditetapkan dalam pelaksanaannya dipastikan menimbulkan kritikan yang konstrukstif. Kritik yang bangun dimulai dari aspek peraturan perundangan, proses pelaksanaan dan dampak yang ditimbulkan dari sebuah kebijakan di ditetapkan Jenis penelitianini adalah Library Research (penelitian kepustakaan dengan menggunakan pendekatan historyfactual approach (pendekatan filosofisfaktual). Analisis kebijakan membandingkan isi/rumusan PP RI No. 55 Tahun 2007 mengenai pendidikan keagamaan Islam dengan teori kebijakan publik. Hasil penelitian yang ditemukan adalah rumusan PP RI No. 55 Tahun 200 terkait tujuan kebijakan publikbersifat regilatif, deregulatif, dinamisasi maupun stabilisasi. Aspek regulatif memberikan pembatasan dan mengatur penyelenggaraan pendidikan keagamaan Islam. Aspek deregulatif memiliki rumusan tujuan membebaskandalam hal penyelenggaraan pendidikan. Aspek dinamisasi sebagai penggerak tujuan pendidikan nasional. Tujuan stabilisasi dimaksudkan untuk melakukan 
pemabatasan terhadap aturan supaya lembaga pendidikan Islam mengikuti Standar pendidikan Nasional.

Kata kunci: Keagamaan; kebijakan; Pendidikan Agama; PP RI No. 55 Tahun 2007.

\section{PENDAHULUAN}

Pemerintah telah menetapkan kebijakan tentang pendidikan Islam dapat terlihat dalam serangkaian history perundang-undangan sistem pendidikan nasional. Selama tiga periodesasi (masa reformasi, orde baru dan orde lama) pemerintah Indonesia mempunyai tiga perundang-undangan yang mengatur sistem pendidikan nasional, yaitu: UU RI No. 20 Tahun 2003 pada masa orde reformasi, UU RI No. 2 Tahun 1989 pada masa orde baru, dan UU RI No. 4 Tahun 1950 Jo UU RI No. 12 Tahun 1954 pada masa orde lama.

Padamasa orde lama Departemen Agama mempunyai perang yang signifikan dalam perkembangan pendidikan Islam pada yang didirikan pada tanggal 3 Januari 1946. Departemen Agama secara intensif banyak memberikan konstribusi dalam perjuangan politik pendidikan Islam di Indonesia. Dengan membentuk satuan khusus yaitu Bagian Pendidikan Agama mengurus masalah pendidikan agama yang termuat dalam nota Islamic Education In Indonesia diantaranya 1) sekolah negeri dan partikulir diberi pengajaran agama, 2) memberikan pengetahuan umum di madrasah, dan 3) Melaksanakan Pendidikan Guru Agama serta Pendidikan Hakim Islam Negeri (Ahmad Darlis, 2018) Pada tahun 20 Januari Tahun 1951 Departemen PKK dan Departemen Agama mengeluarkan ketetapan yang isinya diantaranya pemberian pendidikan agama mulai diberikan sejak sekolah rakyat sampai sekolah tingkat Atas. Adanya ketetepan ini pula pemerintah memiliki perhatian terhadap pengangkatan guru agama dengan menganggarkan seluruh kebutuhan oleh Departemen Agama. Tahun 1966 pendidikan agama menjadi pelajaran wajib sesuai TAP MPRS No. 27 tahun 1966 yang isinya bahwa Pendidikan agama menjadi mata pelajaran pokok dan wajib diikuti murid/mahasiswa sesuai dengan agama masing-masing.

Beberapa ketetapan di atas memunculkan beberapa permasalahan terhadap eksistensi Madrasah dalam sistem pendidikan Nasional yang dipandang tidak menemukan kejelasan. Dengan tidak diakuinya madrasah sebagai pendidikan umum maka lulusan madrasah juga tidak bisa melanjutkan atau pindah ke sekolah umum ataupun pendidikan lebih tinggi diatasnya. Adanya Persoalan ini maka diterbitkannya Surat Keputusan Bersama (SKB) 3 kementrian yaitu Menteri Dalam Negeri, Menteri Agama, dan Menteri Pendidikan dan Pengajaran yang isinya bahwa madrasah memiliki peran dan kedudukan yang sama dengan sekolah umum.

Pemerintah setiap kali menetapkan sebuah kebijakan pendidikan sering kali mendapatkan kritikan yang konstrukstif. Kritik yang bangun dimulai dari aspek peraturan perundangan, proses pelaksanaan dan dampak yang ditimbulkan dari sebuah kebijakan di ditetapkan (Nusa, 2012).

Seringkali sebuah kebijakan di Indonesia mengalami perubahan tergantung pada peta politik dari pemerintahan yang dijalankan, dari segi peta politik dan pemerintahan yang 
menjalankan roda kebijakan. Oleh karena itu, seiring dengan pergantian kepemimpinan, pemerintahan peta politik pendidikan di Indonesia terus mengalami perubahan dan tentunya kebijakan tersebut harus mementingkan rakyatnya. Sejak era reformasi sistem pendidikan nasional telah mengalami perubahan sistem yang dikeluarkan oleh pemerintah pada masa itu. salah satunya UU No. 20 tahun 2003 pasal I ayat I yang berbunyi pendidikan adalah usaha sadar dan terencana demi mewujudkan suasana belajar serta proses pembelajaran bagi peserta didik secara aktif mengembangkan pontensi yang ada dalam dirinya untuk memiliki kemampuan spritual, keagamaan, kepribadian, kecerdasan dan akhlak mulia yang di butuhkan dirinya, masyarakat negara dan bangsa. Dari peraturan pemerintah ini apat dilihat kebijakan pendidikan masih bersifat nasional dan bersifat wacana, padahal banyak sekali lembaga pendidikan sebelum era reformasi, banyaknya lembaga-lembaga nonformal, salah satunya pendidikan agama yang belum mendapat porsi khusus dari kebijakan yang pernah dikeluarkan sebelumnya, sehingga pendidikan agama pada masa itu belum bisa dikatakan pendidikan umum.(Sobri, 2019)

Sebagai penguatan terhadap UU No. 20 tahun 2003maka ditetapkannya Peraturan Pemerintah (PP) No. 552007 tentang Pendidikan Agama dan Keagamaan. Peraturan Pemerintah ini memberikan amanat bahwa pendidikan agama merupakan tanggungjawab Kementerian Agama sebagaimana yang dinyatakan pada Pasal 3 ayat (1) bahwa setiap satuan pendidikan pada semua jalur, jenis, dan jenjang pendidikan wajib menyelenggarakan pendidikan agama, dan ayat (2) bahwa pengelolaan pendidikan agama dilaksanakan oleh Menteri Agama.

Diberlakukannya peraturan pemerintah ini secara otomatis pendidikan keagamaan memiliki kesetaraan dengan pendidikan umum. Meskipun demikian adanya penyesuaian kesetaraan masih berdampak negatif, yaitu adanya persepsi masyarakat terhadap pendidikan Keagaamaan Islam yang pada awalnya untuk memperoleh pengetahuan agama saja, kemudian bergeser untuk mendapatkan pengakuan atau ijazah. Belum lagi adanya eksistensi kelembagaan madrasah diniyah baik dari kurikulum, pendidik, kurikulum, sarana prasarana yang seringkali belum memenuhi standar sistem pendidikan nasional sesuai dalam PP RI No. 19 Tahun 2005.

Pendidikan memiliki kewajiban dalam mempersiapakan masa depan umat manusia dalam pembentukan karakter. Karakter yang memiliki kemampuan spritual, keagamaan, kepribadian, kecerdasan dan nilai moralitas sebagai bagian dari pendidikan nilai (Rofi, Prasetiya, \& Setiawan, 2019; Benny Prasetiya, 2018; Prasetiya, Rofi, \& Setiawan, 2018). Berangkat dari keinginan yang mulai ini setiap kebijakan pendidikan harus mampu menginternalisasi tujuan pendidikan. Kebijakan pendidikan di Indonesia sarat dengan pengaruh kebijakan politik pemerintahan disamping aspek lain seperti perkembangan dan perubahan masyarakat IPTEKS, budaya dan adat istiadat. Bahkan ada asumsi bahwa kebijakan pemerintah dari zaman kolonial, awal dan pasca kemerdekaan hingga masuknya Orde Baru dalam porsi yang kecil memberikan ruang gerak terhadap sistem pendidikan Islam. Adanya tokohtokoh Pendidikan Islam yang masih 
memiliki semangat untuk mempertahankan dan melegalkan terus mengawal setiap kebijakan pemerintah terhadap pendidikan islam sebagaimana terdapat dalam UU RI Nomor 20, tahun 2003 tentang Sistem Pendidikan Nasional (Shabir, 2013)

Memahami masalah kebijakan adalah harus mampu melakukan kajian dalam segala aspek dan menyeluruh terhadap manfaat dan dampak diberlakukannya sebuah kebijakan. Analisis kebijakan yang kompherensif harus mampu menghadirkan solusi terhadap permasalahan yang dihadapi dalam dunia pendidikan bukan menciptakan persoalan-persoalan baru. Artinya kebijakan mampu mengurai permasalahan yang dihadapi (Parker, 2014; Miller, 2013). Masalah menstrukturkan adalah suatu sistem yang mengarahkan kepada hal yang pokok atau mekanisme yang mengarahkan berhasilnya dari semua tahapan-tahapan analisa kebijakan. Menstruktur masalah sangat urgen karena untuk menentukan keberhasilan analis kebijakan dalam hal menyelesaikan atau memecahkan masalah yang salah sebagai upaya mendapat solusi dari masalah (Zamhuri, 2016)

Problematika pendidikan baik pendidikan umum maupun pendidikan agama Islam tidak akan punah dan sirna. Realitas empirik ini tidak bisa lepas atas konseptualisasi pendidikan yang bersifat dinamis, progresif dan kreatif tidak hanya pada aspek materi, kurikulum, model, metode dalam proses pembelajaran (Bahar Agus Setiawan, Benny Prasetiya, 2019). Sistem Pendidikan Nasional adalah sebuah sistem yang terpadu dari semua satuan dan kegiatan pendidikan yang berkaitan satu dengan lainnya untuk mengusahakan tercapainya tujuan pendidikan nasional.
Seiring tuntutan pembaharuan pendidikan di Indonesia, kebijakan pendidikan telah mengalami beberapa kali perubahan. Dalam hal ini kebijakan pendidikan dipandang melalui segi kebijakan publik yang mana kebijakan publik adalah kebijakan yang dibuat oleh negara yaitu berkenaan dengan lembaga eksekutif, legislatif dan yudikatif(Soehartono, 2016; Dewi, 2016; Cairney, 2012).

Persoalan penting yang perlu disorot adalah apakah kebijakan pendidikan bagian kebijakan publik atau kebijakan pendidikan sebagai kebijakan publik. Permasalahan tersebut menjadi penting karena terkait dengan memosisikan pendidikan dalam konteks sektor-sektor publik yang harus dikelola secara serius dan besarnya tingkat urgensi bagi pemerintah di dalam menetapkan prioritas program-program pembangunan (Bakry, 2010).

Kebijakan pendidikan merupakan salah satu kebijakan negara di samping kebijakan-kebijakan lainnya seperti ekonomi, politik, pertahanan, agama dan sebagainya. Dengan demikian, dapat dakatakan bahwa kebijakan pendidikan merupakan sub sistem dari kebijakan negara atau pemerintah secara keseluruhan (Shabir, 2013).

Kebijakan politik dan birokrasi merupakan dua hal paling penting dalam menjalankan roda pemerintahan, tidak terkeculi dalam dunia pendidikan. Dua elemen ini bisa mempengaruhi pelaksanaan pendidikan secara keseluruhan. Kebijakan yang baik akan mandul tanpa dibarengi dengan iklim birokrasi yang sehat dan kondusif. Begitu pula birokrasi tidak akan berjalan dengan efektif dan efesien tanpa ditopang dengan 
kebijakan yang tepat dan baik (Solichin, 2015).

Berangkat dari uraian tersebut diatas maka, penulis mencoba untuk melakukan kajian terhadap Analisis kebijakan pendidikan keagamaan Islam di Indonesia, yaitu PP RI No. 55 Tahun 2007 tentang Pendidikan Agama dan Pendidikan Keagamaan khususnya Studi Tentang PP RI NO. 55 TAHUN 2007)"

\section{METODE PENELITIAN}

Jenis penelitian ini adalah Library Research (penelitian kepustakaan). Penelitian analisis kebijakan ini termasuk salah satu jenis penelitian kepustakaan (Library Research). Pendekatan yang digunakan dalam penelitian ini adalah history-factual approach (pendekatan filosofis-faktual). Analisis kebijakan membandingkan isi/rumusan PP RI No. 55 Tahun 2007 mengenai pendidikan keagamaan Islam dengan teori kebijakan publik. Untuk melaksanakan teknik analisis isi tersebut, maka langkah-langkah yang digunakan adalah dengan menyeleksi sumber data yang relevan, menyusun itemitem yang spesifik, mengurai data atau menjelaskan data, sehingga pada akhirnya dapat memberikan kesimpulan.

\section{HASIL PENELITIAN}

\section{PP RI Nomor 55 Tahun 2007 Tentang Pendidikan Agama Dan Pendidikan Keagamaan.}

Gerakan reformasi di Indonesia khususnya yang berkaitan dengan dunia pendidikan diperkuat dengan prinsip demokrasi, desentralisasi, keadilan, dan hak asasi manusia. Pembaruan system pendidikan nasional dilakukan dalam rangka meniadakan diskriminasi, baik di lembaga pendidikan pemerintah maupun swasta, sekaligus untuk menghilangkan adanya dikotomi antara pendidikan keagamaan dengan pendidikan umum. Sejak UU Nomor 20 Tahun 2003 tentang Sistem Pendidikan Nasional diberlakukan, penghapusan diskriminasi merupakan keniscayaan (Suparta, 2014).

Peraturan pemerintah Nomor 55 Tahun 2007 ini ditetapkan di Jakarta pada tanggal 5 Oktober tahun 2007 ditandatangani oleh Presiden Republik Indonesia Dr. H. Susilo Bambang Yudhoyono. Diundangkan di Jakarta pada tanggal 5 Oktober tahun 2007 oleh Menteri Hukum dan Hak Asasi Manusia Republik Indonesia, ditandatangani oleh Andi Mattalatta. Dengan muatan berjumlah 6 bab, 51 pasal, dan 169 ayat.

Lahirnya PP No. 55 Tahun 2007 secara yuridis adalah sebuah realisasi amanah Pasal 20 ayat 4, Pasal 30 ayat 5, dan Pasal 37 ayat 3 Undang-Undang Nomor 20 tentang Sistem Pendidikan Nasional. Serta Pasal 5 ayat 2 UndangUndang Dasar Negara Republik Indonesia Tahun 1945; Undang-Undang nomor 20 Tahun 2003 tentang Sistem Pendidikan Nasonal (Lembaran Negara Republik Indonesia tahun 2003 Nomor 78 Tambahan Lembaran Negara Republik Indonesia Nomor 4301), dan UndangUndang Nomor 1/PNPS/1065 jo UndangUndang Nomor 5 Tahun 1969 tentang Pencegahan Penyalahgunaan dan/atau Penodaan Agama (Lembaran Negara Republik Indonesia Tahun 1965 Nomor 3, Tambahan Negara Republik Indonesia Nomor 2727.)

Dalam PP Nomor 55 Tahun 2007 menjelaskan bahwa pendidikan Agama merupakan pendidikan yang memberikan pengetahuan serta membentuk sikap, kepribadian, dan keterampilan peserta 
didik dalam mengamalkan ajaran agamanya, yang di laksanakan sekurangkurangnya melalui mata pelajaran/kuliah pada semua jalur, jenjang dan jenis pendidikan. Sedangkan pendidikan keagamaan merupakan pendidikan yang membuat peserta didik untuk mampu menjalankan perannya yang menuntut penguasaan pengetahuan tentang ajaran agama atau menjadi ahli imu agama dan mengamalkan ilmu agamanya di masyarakat.

Adapun turunan dari PP. No. 55 Tahun 2007 menjelaskan pendidikan agama dalam Bab II menyatakan Pasal (2) berbunyi:

a. Pendidikan agama untuk membentuk manusia indonesia yang beriman dan bertakwa kepada Tuhan serta berakhlak mulia dan mampu menjaga kedamaian dan kerukunan hubungan interen atar umat beragama.

b. Pendidikan agama bertujan untuk perkembangan kemampuan yang dimiliki peserta didik agar memahami, menghayati, dan mengamalkan nilainilai agama yang menyerasikan penguasaanya dalam ilmu pengetahuan, seni dan teknologi.

Pasal (3) berbunyi:

a. Semua satuan pendidikan di semua jalur, dan jenjang serta jenis pendidikan dan wajib menyelenggarakan pendidikan agama.

b. Pengelolaan pendidikan agama dilaksanakan menteri agama.

Pasal (4) berbunyi:

a. Pendidikan agama dalam pendidikan formal serta program pendidikan kesetaraan sekurang-kurangnya diselenggarakan dalam bentuk mata pelajaran atau mata kuliah agama. b. Setiap peserta didik dalam satuan pendidikan di semua jenjang, dan jenis pendidikan berhak mendapatkan pendidikan agama sesuai agama yang diyakininya dan diajarkan oleh guru/pendidik yang seagama.

Pasal (5) berbunyi:

a. Kurikulum pendidikan agama dijalankan sesuai Standar pendidikan nasional.

b. Pendidikan agama diterapkan sesuai dengan tahap pertumbuhan dan kejiwaan peserta didik.

Sedangkan tentang pendidikan keagamaan yang diatur pada Bab III Peraturan Pemerintah No. 55 tahun 2007 sebagai berikut:

Pasal (8) yang berbunyi:

a. Pendidikan keagamaan bertujuan mempersiapkan peserta didik agar menjadi anggota masyarakat yang memahami dan mengamalkan nilainilai, ajaran agamanya serta menjadi ahli agama.

b. Pendidikan keagamaan berfungsi untuk membentu peserta didik yang memahami dan mengamalkan seluruh nilai-nilai keagamaan yang berwawasan luas, kritis, kreatif, serta inovatif, dan dinamis dalam rangka mencerdaskan kehidupan bangsa yang bertakwa, beriman dan berakhlak mulia.

Pasal (9) yang berbunyi:

a. Pendidikan keagamaan meliputi seluruh pendidikan yang di akui oleh negara meliputi, Islam Kristen, Katolik, Hindu, Budha, dan Khonghucu.

b. Pendidikan keagamaan di laksanakan padasetiap jenjang pendidikan formal, nonformal, dan informal.

c. Pengelolaan pendidikan keagamaan dilakukan oleh Menteri Agama. 
Pasal (11) yang berbunyi:

a. Peserta didik dalam pendidikan keagamaan jenjang pendidikan dasar dan menengah yang terakreditasi berhak pindah ke tingkat yang setara di Sekolah Dasar (SD), Madrasah Ibtidaiyah (MI), Sekolah Menengah Pertama (SMP), Madrasah Tsanawiyah (MTs), Sekolah Menengah Atas (SMA), Madrasah Aliyah (MA), Sekolah Menengah Kejuruan (SMK) Madrasah Aliyah Kejuruan (MAK) atau bentuk lainnya yang sederajat.

b. Pendidikan keagamaan yang nonformal atau informal dapat dihargai dan dianggap sederajat dengan hasil pendidikan formal keagamaan/umum/kejuruan telah lulus ujian yang diselenggarakan oleh satuan pendidikan terakreditasi yang telah diberi wewenang oleh pemerintah atau pemerintah daerah.

c. Peserta didik dalam pendidikan keagamaan formal, informal, dan nonformal mendapatkan ijazah sederajat pendidikan formal umum/kejuruan semuanya dapat melanjutkan ke jenjang lebih tinggi pada pendidikan keagamaan atau jenis pendidikan lainnya.

Dari penjabaran isi di atas maka pendidikan agama dan keagamaan sebuah keinginan pemerintah dalam memberikan akses pemerataan pendidikan sebagaimana amanat Undang-undang No. 20 Tahun 2003 tentang Sistem Pendidikan Nasional. Pendidikan agama lebih kepada pemberian nilai-nilai agama yang berbentuk mata pelajaran agama pada setiap satuan pendidikan sederajat. Sedangkan pendidikan keagamaan lebih kepada upaya pemerintah menyamaratakan pendidikan baik formal, nonformal, dan informal memberikan fasilitas dan hak-hak yang sama pada tingkat satuan pendidikan agama, seperti Pondok Pesanten, MI, MTs, MA, dan Universitas Agama lainnya. Munculnya PP No. 5 Tahun 2007 mengindikasikan kebijakan pemerintah yang mengakui lembaga pendidikan keagamaan sama dengan pendidikan umum, dimana pendidikan keagamaan ini langsung di bawah naungan Menteri Agama, sehingga pendidikan keagamaan mempunyai hak yang sama baik dari segi bantuan dana, fasilitas, kurikulum, dan sebagainya yang menginduk langsung kepada Kemendikbud (Sobri, 2019).

Berdasarkan pada landasan pustaka dan kerangka Yuridis di atas, jelas yang dimaksud dengan pendidikan agama adalah sebuah program pendidikan Ilmu Agama yang diselenggarakan oleh sekolah formalmSeperti Sekolah Menengah Atas, Sekolah Dasar, dan lain sebagainya. Adapun Pendidikan Keagamaan adalah lembaga pendidikan Agama yang tujuan dan sistem pembelajarannya menitik beratkan pada konstruksi kehidupan keberagamaan yang diyakini. Lembagalembaga ini bergantung pada agamaagama peserta didik masing-masing.

Secara yuridis pula disebutkan, bahwa ada beberapa lembaga pendidikan Islam yang tergolong sebagai Pendidikan Keagamaan: yaitu, pondok pesantren dan madrasah diniyah. Undang-Undang sistem pendidikan Nasional ini mengakomodasi dua model lembaga pendidikan ini sebagai lembaga non-formal, yang berarti, lembaga pendidikan yang dikelola secara sistematis, namun tidak memiliki sertifikasi formal dari pemerintah. Artinya, lembaga non-formal ini dikelola melalui jenjang-jenjang yang sistematis dan terstruktur. Kendati demikian, 
syahadah (ijazah) yang dimiliki peserta didik tidak diakui oleh pemerintah untuk proses jenjang pendidikan tingkat lanjut atau memasuki dunia kerja (Aminullah, 2015)

\section{Analisis Kebijakan PP. RI No. 55 Tahun 2007}

Lembaga pendidikan Islam mengalami beberapa titik kelemahan baik dalam tataran Sumber daya Manusia, sarana prasarana maupun sistem manajerial. Dalam aspek peningkatan sumber daya manusia (SDM), manajemen, dan dana lembaga pendidikan Islam terus mengalami persoalan. Padahal aspek tersebut menjadi daya tawar yang utama di tengah persaingan yag cukup kompetitif. Belum Lembaga pendidikan tinggi Islam seringkali dianggap sebagai lembaga pendidikan yang kurang diminati oleh masyarakat. Sekolah umum selain berlabel islam menjadi pilihan utama untuk mengakses pendidikan (Shabir, 2013)

Peraturan Pemerintah RI No 50 Tahun 2007 memberikan harapan terhadap terbukanya ruang bagi penguatan pendidikan Islam yang memiliki beberapa tujuan kebijakan publik baik yang bersifat regulatif, deregulatif, dinamisasi maupun stabilisasi .

Aspek regulatif ditetapkannya PP RI No. 55 Tahun 2007 bertujuan memberikan pembatasan dan mengatur penyelenggaraan pendidikan keagamaan Islam yang terdapat pada Pasal 14 ayat (1) s.d ayat (3). Pasal ini memberikan pembatasan terhadap bentuk pendidikan keagamaan Islam, yaitu terdiri dari pendidikan diniyah dan pesantren dan melalui jalur apa saja yang dapat diselenggarakan oleh pendidikan diniyah dan pesantren. Pada Pasal 15, rumusan regulatifnya adalah jenjang pendidikan diniyah formal, yaitu terdiri dari jenjang pendidikan anak usia dini, dasar, menengah, dan tinggi. Kemudian, Pasal 16 s.d Pasal 17 membatasi dan mengatur jenjang pendidikan diniyah formal jenjang dasar dan menengah. Kemudian, Pasal 18 ayat (1) s.d ayat (2) mengatur dan membatasi kurikulum wajib pendidikan diniyah formal jenjang dasar dan menengah. Sedangkan, pasal yang mengatur dan membatasi pendidikan diniyah formal jenjang pendidikan tinggi diatur dalam Pasal 20 ayat (1) s.d ayat (3). Yang menjadi persaoalan adalah tidak tercantum pasal yang mengatur pendidikan diniyah formal jenjang pendidikan anak usia dini. Padahal Pasal 15 disebutkan bahwa bahwa jenjang pendidikan diniyah formal terdiri dari pendidikan anak usia dini, pendidikan dasar, pendidikan menengah, dan pendidikan tinggi.

Aspek deregulatif PP RI No. 55 Tahun 2007 memiliki rumusan tujuan membebaskan. Hal ini terlihat pada pada Pasal 16 ayat (3) bahwa penamaan satuan pendidikan diniyah formal jenjang dasar dan menengah adalah hak penyelenggara pendidikan yang bersangkutan. Rumusan deregulatif lainnya pada Pasal 25 ayat (4) bahwa penamaan atas diniyah takmilyah merupakan kewenangan penyelenggara.

Aspek dinamisasi PP RI No. 55 Tahun 2007 bertujuan sebagai penggerak tujuan pendidikan nasional. Rumusan ini terdapat pada Pasal 13 ayat (2) bahwa pendidikan keagamaan dapat didirikan oleh Pemerintah, pemerintah daerah dan/atau masyarakat. Rumusan dengan tujuan dinamisasi memiliki keterkaitan dengan diberikannya hak untuk mendirikan lembaga pendidikan keagamaan Islam oleh swasta/masyarakat. 
Tujuan stabilisasi dalam PP RI No. 55 Tahun 2007 yaitu bersifat untuk melakukan pemabatasan terhadap aturan supaya lembaga pendidikan Islam mengikuti Standart pendidikan Nasional. Hal ini bisa ditemukan dalam Pasal 13 ayat (5) yang menjelaskan bahwa pendirian satuan pendidikan keagamaan diatur oleh Menteri Agama yang berpedoman pada ketentuan Standar Nasional Pendidikan. Pedoman tersebut terkait dengan isi pendidikan/kurikulum, jumlah dan kualifikasi pendidik dan tenaga kependidikan, sarana dan prasarana yang memungkinkan terselenggaranya kegiatan pembelajaran, sumber pembiayaan untuk kelangsungan program pendidikan sekurang-kurangnya untuk 1 (satu) tahun pendidikan/akademik berikutnya, dan sistem evaluasi. Pasal 19 ayat (1) s.d ayat (2) menjelaskan standar ujian nasional pendidikan diniyah formal jenjang pendidikan dasar dan menengah.

\section{PEMBAHASAN}

Analisis di atas memberikan makna bahwa Rumusan PP RI No. 55 Tahun 2007 terkait pendidikan keagamaan Islam mempunyai beberapa tujuan kebijakan publik. Tujuan dari setiap kebijakan publik sebagai landasan untuk tercapainya cita-cita bangsa untuk mengahadirkan setiap kebijakan berlandaskan pada keadilan sosial. Meskipun demikian setiap kebijakan dipastikan menimbulkan dampak kotroversi yang bersifat politis. Kehadiran PP Nomor 55 Tahun 2007 ini juga menimbulkan kontroversi yang berbau politis dan agama. Bagi agama Kristen bahwa lahirnya PP Nomor 55 Tahun 2007 ini sangat merugikan. Bahkan sejak Undang-undang Sistem Pendidikan Nasional Nomor 20 Tahun 2003 pun telah terjadi kontroversi khususnya tentang pendidikan agama dan keagamaan karena sifatnya tidak diterima semua pihak.

Pihak Kristen merasa keberatan sejak lahirnya Undang-Undang Sistem Pendidikan Nasional Nomor 20 Tahun 2003. Dalam Undang-Undang Sistem Pendidikan Nasional Nomor 20 Tahun 2003 ini pasal yang diperdebatkan adalah pasal 12 yang menyebutkan bahwa pendidikan agama adalah hak setiap peserta didik. "Setiap peserta didik pada setiap satuan pendidikan berhak mendapatkan pendidikan agama sesuai dengan agama yang dianutnya dan diajarkan oleh pendidikan yang seagama", (Pasal 12 ayat 1 a).

Menurut pihak Kristen bahwa PP Nomor 55 Tahun 2007 tentang pendidikan agama dan pendidikan keagamaan adalah perkawinan kepentingan politik negara dan Islam untuk menekan, membatasi bahkan mematikan kehidupan dan perkembangan umat non-Islam dan lembaga-lembaga pendidikannya dan kependidikannya melalui suatu senjata halus (simbolik) sehingga proses menekan, membatasi dan mematikan kehidupan dan perkembangan tersebut berjalan secara lamban namun pasti dan tak disadari. Alasan-alasan yang diajukan pihak Kristen tersebut di atas secara umum terlihat ilmiah dan argumentatif. Namun terdapat indikasi lain yang menjadi alasan utama penolakan mereka terhadap PP Nomor 55 Tahun 2007 ini. Indikasi tersebut lebih bermuatan ideologi. Sebab dengan lahirnya PP Nomor 55 Tahun 2007 ini program kristenisasi mereka bidang pendidikan akan terhambat. Indikasi ini bukan tanpa alasan. Dalam hal ini, tidak sedikit muslim korban pemurtadan dilatarbelakangi oleh kesalahan orangtua mereka 
menyekolahkan atau menguliahkan anaknya di sekolah atau di kampus milik non-muslim. Padahal, di institusi umum atau negeri yang muslimnya lebih banyak saja, kasus pemurtadan tidak sedikit ditemui (Ahmad Darlis, 2108).

PP Nomor 55 Tahun 2007 jika dianalisis lebih mendalam sesungguhnya tidak satu agamapun yang dirugikan oleh kebijakan ini. Karena lembaga pendidikan agama manapun tidak dirugikan dengan memberikan pelajaran agama bagi peserta didik yang seagama dengan gurunya dan ini sesuaisdengan UUD 1945 yang memberikan jaminan terhadap warga negera untuk memperoleh pendidikan agama sesuai dengan keyakinan yang anutnya. Dengan adanya guru agama ataupun pelajaran agama disebuah sekolah yang tidak sama dengan ciri dari sekolah tersebut tidak akan menghilangkan keunggulan dari sekolah tersebut. Namun adanya guru agama, peserta didik yang berbeda akan membuka peluang untuk saling menghargai dan menghormati keyakinan yang berbeda. Ini menjadi penting untuk membangun semangat pluralisme dalam lingkungan pendidikan untuk membiasakan hidup secara toleran pada tatanan masyarakat yang berbeda.

Meskipun demikian kebijakan PP PP Nomor 55 Tahun 2007 memberikan dua dampak kecurigaan motif politik dalam konteks pendidikan Islam khususnya Pondok Pesantren dan Madrasah Diniyah. Pertama, pondok pesantren tidak akan lagi memiliki kebebasan dalam upaya mengatur dan mengelola kurikulum yang akan diberikan kepada peserta didiknya. Ini dianggap penting bagi pemerintah untuk memberikan pembatasan pada pondok pesantren yang radikal dan tidak berasaskan pada ideologi Pancasila. Kedua, adanya peraturan ini, secara implementatif akan dijadikan alat politik kepala daerah dalam upaya meraup suara di daerah-daerah yang mayoritas beragama Islam, dan condong pada tradisionalisme.

Terbukti lahirnya PP 55/2007, beberapa daerah kabupaten/kota mengeluarkan peraturan daerah (Perda). Daerah-daerah yang telah mengeluarkan Perda adalah Kabupaten Indramayu melalui Perda Nomor 2, Tahun 2003, Kabupaten Pandeglang melalui Perda Nomor 27, Tahun 2007, Kabupaten Pesisir Selatan melalui Perda Nomor 8, Tahun 2004, dan Kabupaten Serang melalui Perda Nomor 1, Tahun 2006, serta Kota Serang melalui Perda Nomor 1, Tahun 2010 (Fauzi \& Nikmatullah, 2018). Kebijakan ini dianggap sebagai tujuan politis penguasa untuk mendapat simpati dari kelompok mayoritas (umat islam). (Karimullah \& Susanto, 2015).

Adapun anggapan kedua ini, bisa dilihat dari sudut implementasi kebijakankebijakan di daerah-daerah tertentu. Misalnya kebijakan bantuan beasiswa bagi Guru Madrasah Diniyah di Jawa Timur. Kebijakan ini awalnya menuai banyak kritik, baik dari akademisi ataupun sikap pemerintah sendiri. Kritik ini didasarkan pada pertama, secara historis, Madrasah Diniyah adalah kelembagaan pendidikan yang dibangun oleh masyarakat dan dikelola secara mandiri oleh masyarakat. Kedua, ada usaha sistematis untuk memberikan bantuan profesionalisme dan tunjangan bagi guru Madrasah Diniyah, yang secara Undang-Undang Sistem Pendidikan Nasional tidak diakui dan diatur secara formal. Ketiga, adalah tanggapan Menteri Dalam Negeri, Gamawan Fauzi yang menyebut bahwa 
bantuan Beasiswa Pendidikan dan tunjangan untuk Guru Madrasah Diniyah inkonstitusional dan tidak berdasar. Disamping itu dampaknya adalah ada beberapa pesantren yang dulunya tidak memiliki Madrasah Diniyah, sekarang berlomaba-lomba untuk mendirikan Madrasah Diniyah agar dapat mengakses anggaran pemerintah (Aminullah, 2015)

Kuatnya kontrol pemerintah dalam PP No 55 tahun 2007 tentang pendidikan agama dan keagamaan menjadikan pondok pesantren dan madrasah diniyah tereduksi dalam pengembangannya. Sebab peraturan pemerintah ini akan mengintervensi sampai pada formalisasi hingga kurikulum pendidikan di dalamnya. Berdasarkan pada pemikiran Antonio Gramsci, hegemoni tidak selalu bermakna proses pemaksaan dan pengetatan situasi sosial tertentu. Hegemoni adalah on going process yang dibangun melaluibanyak kanal kehidupan manusia. PP. No. 55 Tahun 2007, juga perlu kita sadari sebagai upaya pemerintah untuk mengontrol kegiatan-kegiatan pendidikan keagamaan. Modelnya, melalui standarisasi kurikulum, kualifikasi guru, danbeberapa aturan lain yang sudah dijelaskan sebelumnya.

\section{KESIMPULAN}

Latar belakang diterbitkannya PP. No. 55 Tahun 2007 tentang pendidikan Agama dan Keagamaan adalah amanat Undang-Undang No 20 Tahun 2003, tentang Sistem Pendidikan Nasional. Dari sisi sosiologis kebijakan ini karena kegelisahan pertumbuhan pondok pesantren dan madrasah diniyah yang pesat, serta tidak adanya kontrol aktif dari pemerintah menjadi acuan lahirnya peraturan pemerintah ini. PP. No. 55 Tahun 2007 salah satu produk politik pemerintah dalam dalam melakukan kontrol pendidikan agama dan keagamaan. Pelaksanaan pada kebijakan ini adalah adanya standarisasi kurikulum, kualifikasi guru, dan sanksi bagi yang melakukan pelanggaran. Kebijakan ini adalah bagian dari sebuah ijtihad politik pemerintah sebagai bagian dari sistem hegemonic dominasi kuat dalam melakukan pembatasan terhadap pendidikan agama dan keagamaan untuk mengakomodasi kepentingan-kepentingan dan hak-hak yang dimiliki lembaga pendidikan keagamaan

Hasil penelitian yang ditemukan adalah rumusan PP RI No. 55 Tahun 2007 memiliki tujuan kebijakan publikbersifat regilatif, deregulatif, dinamisasi maupun stabilisasi. Aspek regulatif memberikan pembatasan dan mengatur penyelenggaraan pendidikan keagamaan Islam. Aspek deregulatif memiliki rumusan tujuan membebaskandalam hal penyelenggaraan pendidikan. Aspek dinamisasi sebagai penggerak tujuan pendidikan nasional. Tujuan stabilisasi dimaksudkan untuk melakukan pembatasan terhadap aturan supaya lembaga pendidikan Islam mengikuti Standar pendidikan Nasional.

\section{DAFTAR PUSTAKA}

Ahmad Darlis. (2108). Analisis Terhadap Kebijakan Pemerintah Tentang Pendidikan Agama Dan Keagamaan (Melacak Dampaknya Terhadap Pendidikan Islam). Jurnal Tarbiyah, 25(2), 21-40.

Aminullah, M. (2015). Analisis PP. NO 55 Tahun 2007 Tentang Pendidikan Agama Dan Keagamaan Perspektif Antonio Gramsci. Jurnal Kependidikan Islam, 6(55), 49-76. 
Bahar Agus Setiawan, Benny Prasetiya, S. R. (2019). Implementasi Tasawuf dalam Pendidikan Agama Islam: Independensi, Dialog, dan Integrasi. Potensia, 5(1), 64-78.

Bakry, A. (2010). Kebijakan Pendidikan sebagai Kebijakan Publik. Jurnal Medtek, 2(April), 1-13.

Benny Prasetiya, S. R. (2018). Pendidikan Nilai: Konsep Dan Implementasinya Dalam Dunia Pendidikan. Jurnal Imtiyaz, 2(1), 15-33.

Cairney, P. (2012). Understanding Public Policy. In Understanding Public Policy. https://doi.org/10.1007/9780-230-35699-3

Dewi, R. (2016). Kebijakan Pendidikan Di Tinjau Dari Segi Hukum Kebijakan Publik.Jurnal Ilmu Hukum, 7(2), 58-71.

Fauzi, A., \& Nikmatullah, C. (2018). Pelaksanaan Pendidikan Madrasah Diniyah Di Kota Serang. Jurnal Pendidikan Dan Kebudayaan, 1(2), 157.

https://doi.org/10.24832/jpnk.v1i2. 763

Karimullah, \& Susanto, E. (2015). Kebijakan Pendidikan Nasional Bidang Agama Islam.Tadris, 10(1), 104-118.

Miller, J. (2013). Religious Extremism, Religious Education, And The Interpretive Approach. Religion and Education, 40(1), 50-61. https://doi.org/10.1080/15507394.2 013.745362

Parker, L. (2014). Religious education for peaceful coexistence in indonesia? South east asia research, 22(4), 487-504.

https://doi.org/10.5367/sear.2014.0
231

Peraturan Pemerintah. No. 55, Tahun 2007. Tentang Pendidikan Agama dan Keagamaan

Peraturan Menteri Agama Republik Indonesia Nomor 3 Tahun 2012.

Prasetiya, B., Rofi, S., \& Setiawan, B. A. (2018). Penguatan Nilai Ketauhidan Dalam Praksis Pendidikan Islam. Journal of Islamic Education (JIE), III(1), 115.

Rofi, S., Prasetiya, B., \& Setiawan, B. A. (2019). Pendidikan Karakter Dengan Pendekatan Tasawuf Modern Hamka dan Transformatif Kontemporer. Intiqad, 11(2), 396414.

Shabir, M. U. (2013). Kebijakan Pemerintah Dan Pengaruhnya Terhadap Pendidikan Islam Di Indonesia Sejak. Lentera Pendidikan, 16(2), 166-177.

Sobri, R. (2019). Politik Dan Kebijakan Tentang Pendidikan Agama Dan Keagamaan Di Indonesia (Analisis Kebijakan PP No. 55 Tahun 2007). Edukasi Islami: Jurnal, 08(01), 109-124.

Soehartono, H. T. P. (2016). Kebijakan Pendidikan Di Tinjau Dari Segi Hukum Kebijakan Publik. Jurnal Ilmu Hukum, 7(2), 58-71.

Solichin, M. (2015). Implementasi Kebijakan Pendidikan Dan Peran Birokrasi. Jurnal Studi Islam Oktober, 6(2), 1978-306. https://doi.org/1978-306X

Suparta, H. M. (2014). Masa Depan Pesantren Pasca UU 20/2003 Tentang Sistem Pendidikan NasionaL Dan PP 55/2007 Tentang Pendidikan Agama DanPendidikan 
Keagamaan. ANALISIS: Jurnal

Studi Keislaman, 14(1), 173-200.

Zamhuri. (2016). Analisis Kebijakan

Pendidikan Islam Menstruktur

Problem Kebijakan Kasus MIS

Sore. 1-22. 